\title{
EFFECTS OF THE USE OF CONTROL SYSTEMS ${ }^{1}$
}

\author{
CORTLANDT CAMMANN
}

The University of Michigan

\begin{abstract}
This research explored the moderating effects of subordinate participation in decision making and subordinate job difficulty on their responses to different uses of control systems by their superiors. In a sample of managers from a moderately large U.S. organization, both of these factors were found to moderate the ways subordinates responded to the perceptions that their superiors used control systems for goal setting, evaluation, problem solving, and contingent reward allocations.

The results of the study indicated that the use of control systems for contingent reward allocation produced defensive subordinate responses under all conditions, but also produced the functional response of effort when subordinate participation was low and job difficulty high. The use for goal setting appeared to result in functional responses when subordinate participation was high, and in dysfunctional responses when participation was low. The use for evaluation and the use for problem solving both seemed to be aspects of a collaborative developmental use of the control systems. This use pattern appeared to have primarily functional effects, although the results were more functional when the subordinate jobs were not difficult, and when they participated in decision making. Based on the results several propositions are formulated for future testing.
\end{abstract}

Over the past few years, an increasing amount of research has focused on the way managers use control systems to influence the behavior of their subordinates. This research indicates that budgets, financial reports, and other feedback-based control systems are important tools for influencing subordinate actions. As is the case with most tools, control systems can be used well or poorly. Used well they can produce functional results such as motivation and satisfaction (e.g. Hofstede, 1967; Searfoss \& Monczka, 1973; Stedry \& Kay, 1964). Used poorly they can have dysfunctional effects such as resistance and defensiveness (e.g. Argyris, 1952; Blau, 1955; Jasinsky, 1956; Hopwood, 1973; Whyte, 1955).

In spite of the research which has been done, the nature of the relationships between control system uses and the outcomes they produce remain unclear. Few uses appear to produce the same results in all situations. As Hopwood (1974) has pointed out, the way people respond to uses of control systems by others, particularly superiors, probably depends upon the context within which the use occurs. Uses which produce functional responses in one situation can be expected to result in dysfunctional reactions in another.

The problem facing researchers is to identify the crucial situational characteristics which moderate these relationships, and to discover the ways in which they influence the outcomes which result from different uses of control systems. The purpose of the research reported here was to explore one aspect of this problem. It examined the ways in which the contextual characteristics of subordinate participation in decision making and subordinate job difficulty moderated the subordinates responses to their superior's uses of control systems in different ways. Since the purpose of the research was exploratory, it focused on discovering, empirically, the ways in which the

\footnotetext{
${ }^{1}$ This research was supported by a predoctoral grant from the National Institute for Mental Health and by the site organization. The author would like to thank Edward Lawler, Richard Hackman, Gerrit Wolf, Stanley Seashore, David Nadler, Jeanne Herman and Robert Cooke for their help and advice on various aspects of the research. Special thanks needs to be given to the organization which participated in the study and to all of the people who contributed their time and ideas to the researcher.
} 
responses were contextually contingent, and hypotheses were not generated in advance.

\section{SUPERIOR USES OF CONTROL SYSTEMS}

Four different uses of control systems were chosen for exploration in this research. Each of these uses has been identified in previous research studies as ways in which control systems can be used to influence subordinate behavior.

\section{Use for goal setting}

Managers can use control system measures as a vehicle for clearly communicating their expectations for future performance through a process of goal setting (e.g. Stedry, 1960; Hofstede, 1967). As long as subordinates are motivated to meet their superior's expectations, control system goals can be expected to influence their behavior.

\section{Use for evaluation}

Managers can use control system information as a focus for reviewing subordinate performance, and providing feedback on its adequacy through a process of evaluation (e.g. Hopwood, 1973). Since subordinates generally try to obtain favorable evaluations from their superiors, this use of system information can have an important effect on the way they act.

\section{Use for contingent reward allocation}

Managers can use control system information as a basis for allocating organizational rewards, thus making them contingent on good performance (e.g. Lawler, 1971; 1976). When the rewards are valued by subordinates this contingency should motivate them to try to perform well (e.g. Vroom, 1964).

\section{Use for problem solving}

Managers can use control system information to help identify and solve work related problems (e.g. Hopwood, 1973). This work-oriented feedback can influence the way subordinates perform their work, but is generally more work focused than the personally directed feedback which occurs during evaluation.

\section{SUBORDINATE RESPONSES}

The research on control systems has shown that subordinates can respond in many different ways when these systems are used to influence their behavior. Four different types of responses were chosen for measurement in this study.

\section{Effort}

A number of studies have shown that control systems can be used to motivate subordinates to put effort into increasing their job performance (Hofstede, 1967; Stedry, 1960).

\section{Job satisfaction}

Control system can influence the way subordinates feel about their jobs, as well as their motivation to perform (Argyris, 1952; Hofstede, 1967).

\section{Tactical responses}

Subordinates can respond to control systems use with a variety of tactical responses designed to keep control system results from hurting them. Planning work to keep measured performance high, spending time checking control system calculations to be sure no mistakes were made, and carefully documenting external events which effect the performance measures are all examples of tactical responses that have been identified in previous research (Argyris, 1962; Hopwood, 1973; Whyte, 1955).

\section{Defensive orientation}

Subordinates can respond to control system use by developing a defensive orientation which can reduce the validity of the information contained by the system. This orientation often includes setting low goals so that results will look good, worrying primarily about performance measures, not real performance, and altering the information which goes in to the control system (Argyris, 1952; Jasinsky, 1956; Hofstede, 1967; Hopwood, 1973; Onsi, 1973).

These responses were chosen because they appeared to measure a range of the possible responses. High subordinate motivation and satisfaction are generally functional outcomes since they increase the amount of managerial energy available to an organization. Tactical responses are somewhat dysfunctional for the organization, since they represent use of the subordinate's time and energy in ways that have 
little organizational value. The development of a defensive orientation is also dysfunctional for the organization as it reduces the effectiveness of the control systems and the validity of the information available to decision makers (Onsi, 1973).

\section{MODERATING VARIABLES}

Two moderating variables were considered in this study: the degree of subordinate participation in decision making and the degree of difficulty of the subordinate's job. The effects of participation were examined because subordinate responses to attempts to influence their behavior can be expected to vary depending on their power in the influence process (Coch \& French, 1948; Deutsch \& Krauss, 1962; French, Kay \& Meyer, 1966; Tannenbaum, 1962). As a result, participation can be expected to influence the way subordinates respond to their superiors' use of control systems. The importance of participation has been demonstrated in a number of different studies (Hofstede, 1967; Searfoss \& Monczka, 1973). However, the results of these studies have not been consistent. Hopwood (1973) found, for example, that subordinate participation in setting budgetary goals produced functional results in the context of one type of superior-subordinate relationship and dysfunctional results in the context of others. Findings such as these have led Tosi (1974) to argue that participation in using the control system is probably not as critical as the extent of participation in the superior-subordinate relationship. As a test of this possibility, participation was employed as a moderating variable in this study.

The difficulty of the subordinates' job was chosen as a moderating variable for two different reasons. First, the difficulty of the subordinates' job could be expected to effect the likelihood that they will respond dysfunctionally to control system uses. When their jobs are easy, the subordinates should have little difficulty performing well, and thus no reason to behave tactically or defensively. When their jobs are difficult, dysfunctional responses appear more likely. Second, while there is a considerable amount of research that has examined the effects of using control systems to increase the difficulty of a subordinate's job, there is not much research that has examined the effects of using control systems under different conditions of job difficulty. Thus, while it is clear that difficult control system goals can motivate subordinates to work hard (Stedry, 1960; Stedry \& Kay, 1964; Hofstede, 1967), it is not known if there is any particular value in having the goals set in control system terms, or if other uses of control systems will produce more functional or dysfunctional responses when the subordinates have difficult jobs. To examine these questions job difficulty was used as a moderating variable.

\section{METHOD}

\section{The site}

In order to explore the relationships between uses of control systems and subordinate responses, data were collected from all of the managerial level personnel in two functional divisions of a moderately large private utility, located in the northeastern part of the United States. This organization maintained an extensive control system based on a wide variety of performance measures, including measures of the effectiveness of customer service, employee productivity, adequacy of equipment maintenance, and expenditure in both absolute terms and in relationship to budgets. Each month these performance measures were collected and fed back to the company's managers. The performance measures were broken down into units which roughly corresponded to each manager's (foreman level and above) area of responsibility. Each manager above the foreman level received the measures describing both his own performance and the performance of the people who reported to him. Although foremen were not given their own performance data directly, this information was generally made available to them by their superiors. As a result, the control system generally insured that each manager received measures describing the effectiveness of the organization in his own area of responsibility, and he knew that his superior was receiving the same information.

\section{Data collection}

The data collection involved two steps. First, the researchers interviewed 45 managers from different levels in the two divisions being studied in order to explore the structure of the control system. These interviews were semi-structured in form and served to familiarize the researcher with the functioning, language and climate of the organization. 
TABLE 1. Measures, sample items, and reliability estima tes

\begin{tabular}{|c|c|c|c|}
\hline & & Reliability* & $\begin{array}{r}\text { Scale } \\
\text { length }\end{array}$ \\
\hline $\begin{array}{l}\text { 1. Managerial participation in } \\
\text { decision making }\end{array}$ & $\begin{array}{l}\text { (My superior) asks me to participate in } \\
\text { making important decisions }\end{array}$ & .63 & 4 \\
\hline $\begin{array}{l}\text { 2. Managerial experiences of } \\
\text { job difficulty }\end{array}$ & $\begin{array}{l}\text { On my job, I have to achieve very difficult } \\
\text { objectives }\end{array}$ & .55 & 3 \\
\hline $\begin{array}{l}\text { 3. Superior's use for goal } \\
\text { setting }\end{array}$ & $\begin{array}{l}\text { (My superior) sets goals for me in terms of } \\
\text { feedback measures }\end{array}$ & .48 & 4 \\
\hline $\begin{array}{l}\text { 4. Superior's use for general } \\
\text { evaluation }\end{array}$ & $\begin{array}{l}\text { (My superior's) evaluation of me depends on } \\
\text { my performance on feedback measures }\end{array}$ & .55 & 7 \\
\hline $\begin{array}{l}\text { 5. Superior's use for contingent } \\
\text { reward allocation }\end{array}$ & My pay depends on my results measures & .69 & 5 \\
\hline $\begin{array}{l}\text { 6. Supervisor's use for problem } \\
\text { solving }\end{array}$ & $\begin{array}{l}\text { (My supervisor) responds to low results by } \\
\text { trying to help me find out where the problem } \\
\text { lies }\end{array}$ & .68 & 6 \\
\hline 7. Manager's tactical responses & $\begin{array}{l}\text { If my results are low, I check to be sure no } \\
\text { one has made a mistake }\end{array}$ & .41 & 4 \\
\hline 8. Manager's defensive orientation & $\begin{array}{l}\text { I have to be careful not to set my results goals } \\
\text { too high or they will catch up with me }\end{array}$ & .57 & 4 \\
\hline 9. Managerial effort & I work very hard on my job & .62 & 2 \\
\hline 10. Managerial satisfaction & I enjoy the type of work I do on my job & .56 & 4 \\
\hline
\end{tabular}

The information gathered in the interviews served as the basis for developing a questionnaire to gather systematic data on the functioning of the control system. This questionnaire addressed a range of issues concerning the use of the control system within the organization and was sent to all 525 managers in the two function divisions being studied. The questionnaires were sent with a letter from the manager's department head and a letter from the researcher. The confidentiality of all responses was guaranteed by the researcher and the department head asked the managers to participate in the study.

\section{Sample}

Useable responses were returned by 357 (68\%) of the managers. Twenty of the responses were from top level of managers in these divisions (74\% response rate). $52(69 \%)$ were from managers at the next level down, and $285(67 \%)$ were from foremen. All of these managers had direct line responsibility for getting the utility's product to customers and for keeping the customers properly serviced.

\section{Measures}

The questionnaire asked managers a number of questions about the way their superiors used the control systems, about their own response to the system, and about their job in general. ${ }^{2}$ These questions were in the form of statements and the managers were asked to indicate, on a seven-point scale, the degree to which they agreed with the statement as a description of their superior, their job, or their own behavior. These questions were formed into ten a priori scales for the purposes of this study. Table 1 summarizes the scales that were formed showing a sample item, and the Spearman-Brown estimate of the internal consistency reliability for each scale.

The first two measures shown in Table 1 operationalize the moderating variables of interest: the extent to which the respondents participated in decision making, and their experienced job difficulty. The next four scales measured the respondents' perceptions of their superior's use of control systems: the use for goal setting, the use for evaluation, the use for contingent reward allocation, and the use for problem solving. With

${ }^{2} A$ copy of the full questionnaire is available from the author on request. 
one exception, these scales directly operationalize the concepts as they were defined earlier. The exception is the measure of the superior's use of the control system measures for problem solving. This measure includes three negatively weighted items which reflected the use of control system information to reactively pressure subordinates to perform better when their results were poor. Thus a low score on the use for problem solving indicates a reactive response to negative information, rather than simply not using the information for problem solving. The final four measures operationalized the respondents' job responses: effort, satisfaction, tactical responses, and the development of a defensive orientation.

\section{RESULTS}

The relationships among the moderating variables and the measures of the superiors' uses of the feedback system are summarized by the correlations shown in Table 2. All of these correlations, and all those presented later, are controlled for managerial level. These data show that the moderating variables are relatively independent $(r=-.09)$. They also show that subordinates who felt that they participated in decision making generally described their superiors as making more use of the performance measurement systems for goal setting and problem solving, and that those who felt that their jobs were more difficult described their superiors as using the system more for evaluation, contingent reward allocation, and problem solving.

The only significant relationship between the measures of managerial participation and mana- gerial responses was with managerial satisfaction ( $r$ $=.18, p<.05$ ). This indicates that participation did not generally have a direct effect on the managerial responses. The managers' experiences of difficult job goals related significantly to managerial effort and defensive orientation ( $r$ 's $=$ $.23, .19, p<.01$ ), indicating a general tendency for managers with more difficult jobs to work harder and to respond more defensively.

In order to examine differences in the relationships between control system uses and subordinate responses in different contexts, the measures of the subordinate's perceptions of their participation in decision making and their job difficulty were used to partition the sample into four groups, as shown in Table 3 . The subordinates were classified as relatively high on each of the contextual variables if they fell above the sample mean on the measures, and low otherwise.

\section{Impact of situational moderators}

The next step in the analyses was to determine whether or not the situational variables moderated the pattern of relationships between the respondents' perception of their superiors' uses of control systems and their responses. This was accomplished by testing the homogeneity of the canonical relationships within the four subsamples, using a method similar to the test for homogeneity of regression described by Kerlinger \& Pedhauzer (1973). First, the canonical correlations were calculated for the total sample using the subordinates' responses as dependent variables and the superiors' uses of control systems, the subordinates' organizational level, and three dummy variables defining subsample membership as the independent variables. This analysis was

TABLE 2. Correlations of contextual measures with the independent measures

\begin{tabular}{|c|c|c|c|c|c|c|}
\hline 1. Managerial participation & 1.00 & & & & & \\
\hline $\begin{array}{l}\text { 2. Manager's experienced job } \\
\text { difficulty }\end{array}$ & -.09 & 1.00 & & & & \\
\hline $\begin{array}{l}\text { 3. Superior's use of measures } \\
\text { for goal setting }\end{array}$ & .24 & .05 & 1.00 & & & \\
\hline $\begin{array}{l}\text { 4. Supervisor's use of measures } \\
\text { for evaluation }\end{array}$ & -.13 & .17 & .32 & 1.00 & & \\
\hline $\begin{array}{l}\text { 5. Superior's use of measures } \\
\text { for contingent reward allocation }\end{array}$ & -.05 & .20 & .20 & .45 & 1.00 & \\
\hline $\begin{array}{l}\text { 6. Superior's use of measures } \\
\text { for problem solving }\end{array}$ & .41 & .20 & .41 & -.41 & -.22 & 1.00 \\
\hline
\end{tabular}

Correlations above 0.14 are significant for $p<.01$ 
TABLE 3. Four group partitions of the sample

\begin{tabular}{|c|c|c|}
\hline & Low participation & High participation \\
\hline Low job difficulty & $\begin{array}{l}\text { Subordinates perceiving } \\
\text { relatively low participation and } \\
\text { relatively low job difficulty: } \\
\qquad n=90\end{array}$ & $\begin{array}{l}\text { Subordinates perceiving } \\
\text { relatively high participation and } \\
\text { relatively low job difficulty: } \\
\qquad n=101\end{array}$ \\
\hline High job difficilty & $\begin{array}{l}\text { Subordinates perceiving } \\
\text { relatively low participation and } \\
\text { relatively high job difficulty: } \\
\qquad n=77\end{array}$ & $\begin{array}{l}\text { Subordinates perceiving } \\
\text { relatively high participation and } \\
\text { relatively high job difficulty: } \\
\qquad n=89\end{array}$ \\
\hline
\end{tabular}

TABLE 4. Regressions of the measures of supervisors' uses of control systems on measures of subordinate responses-low participation, low job difficulty sample $f$

\begin{tabular}{lcccccc}
\hline $\begin{array}{c}\text { Subordinate } \\
\text { responses }\end{array}$ & $r^{2}$ & $\begin{array}{c}\text { Use for } \\
\text { problem solving* }\end{array}$ & $\begin{array}{c}\text { Use for } \\
\text { goal setting* }\end{array}$ & $\begin{array}{c}\text { Use for } \\
\text { evaluation* }\end{array}$ & $\begin{array}{c}\text { Use for } \\
\text { contingent } \\
\text { reward } \\
\text { allocation* }\end{array}$ & $\begin{array}{c}\text { Managerial } \\
\text { level* }\end{array}$ \\
\hline Effort & $.17 \S$ & $.27 \|$ & -.12 & $.23 \neq$ & -.10 & -.28 \\
Job satisfaction & .05 & $(.33)$ & $(-.12)$ & $(.23)$ & $(-.10)$ & $(-.17)$ \\
Tactical responses & $.15 \neq$ & .08 & -.03 & -.07 & -.17 & -.29 \\
Defensive orientation & $.20 \|$ & .02 & $(-.03)$ & $(.06)$ & $(-.16)$ & $(-.16)$ \\
& & $(.03)$ & $(.10)$ &. .05 & .15 & $.58 \|$ \\
& $(-.328$ & .14 & .08 & $.14)$ & $(.32)$ \\
& & $(-.34)$ & $(.12)$ & $(-.07)$ & $(.21)$ & $.39 \ddagger$ \\
\end{tabular}

\footnotetext{
* Sample Beta's and partial correlations.

$\dagger$ Numbers in parantheses are the partial correlations of the independent variables with the dependent variable controlling for the other independent variables.
}

$\ddagger p<.05$.

$\S p<.01$.

$\| p<.005$.

repeated, substituting interaction variables (superiors' use $X$ subsample membership) for the measures of the superiors' uses of the control system.

The results of the analyses were then compared to find out if the second analysis accounted for significantly more variance in the dependent variables than the first. The resulting significance test indicated that the canonical analyses using the interaction variables did account for significantly more variance $\left(\Lambda_{1}=.524, \Lambda_{2}=.429, \chi 2\right.$ diff $=$ $67.72, p<.05, d f=48)$. This finding implies that the relationships between the dependent and independent measures, controlling for managerial level, were not the same across the four subsamples, and that the contextual variables did make a difference. As a result, the relationships among the independent and dependent variables were examined within the separate subsamples. In performing these analyses, multiple regressions were used, rather than canonical correlations, as it was felt that the results would be more interpretable. ${ }^{3}$

\section{Low participation, low job difficulty sample}

The regression equation relating the measures of the uses of control systems with the measures of the subordinate responses are shown in Table 4.

\footnotetext{
${ }^{3}$ The canonical analysis was performed for each sample, and the results were generally consistent with the
interpretation presented here.
} 
The results indicate that for this sample, none of the measures of the use of control systems related to the measures of tactical responses or job satisfaction, and that the measure of the use for goal setting did not relate significantly to any of the responses. The subordinates' effort was positively related to their perception that their superiors used the control systems for problem solving and evaluation. The development of a defensive orientation was positively related to the subordinates' perceptions that their superiors used the systems for contingent reward allocation, and negatively related to their perception that it was used for problem solving.

\section{Low participation, high job difficulty sample}

The regression equations for the low participation, high job difficulty sample are shown in Table 5 . The results indicate that only the subordinates' perception that their superiors used the control systems as a basis for contingent reward allocation related positively to their effort, and only their perception of the use for problem solving related positively to their job satisfaction. Tactical responses related positively to the subordinates' perception that their superiors used the control systems for contingent reward allocation, and the measure of defensive orientation related to both this perception and to the perception that the control system was used for goal setting.
High participation, low job difficulty sample

Table 6 shows that regression equations for the high participation, low job difficulty sample. These results indicate that in this sample the subordinates' effort was positively related to the use of the control systems for problem solving, goal setting, and evaluation, but not for contingent reward allocation. The subordinates' job satisfaction was slightly negatively related to the use of control systems for contingent reward allocation, but not to any of the other uses. The measure of the subordinates' tactical responses was positively related to the use for goal setting, while the measure of defensive orientation was negatively related to the use for problem solving, and positively related to the use for contingent reward allocation.

\section{High participation, high job difficulty sample}

The results for the high participation, high job difficulty sample are shown in Table 7 . The data indicate that job satisfaction was positively related to use for goal setting and that tactical responses were positively related to the use for contingent reward allocation. The development of a defensive orientation was related to both the uses for goal setting and contingent reward allocation. The regression relating the independent variables with effort is somewhat puzzling. The overall regression was significant, but none of the independent

TABLE 5. Regressions of the measures of supervisors' uses of control systems on measures of subordinate responses-low participation, high job difficulty sample $\dagger$

\begin{tabular}{|c|c|c|c|c|c|c|}
\hline $\begin{array}{l}\text { Subordinate } \\
\text { responses }\end{array}$ & $r^{2}$ & $\begin{array}{c}\text { Use for } \\
\text { problem solving* }\end{array}$ & $\begin{array}{l}\text { Use for } \\
\text { goal setting* }\end{array}$ & $\begin{array}{l}\text { Use for } \\
\text { evaluation* }\end{array}$ & $\begin{array}{l}\text { Use for } \\
\text { contingent } \\
\text { reward } \\
\text { allocation* }\end{array}$ & $\begin{array}{c}\text { Managerial } \\
\text { level* }\end{array}$ \\
\hline Effort & .10 & $\begin{array}{l}.07 \\
(.09)\end{array}$ & $\begin{array}{l}-.12 \\
(-.12)\end{array}$ & $\begin{array}{l}.03 \\
(.03)\end{array}$ & $\begin{array}{l}.22 \ddagger \\
(.25)\end{array}$ & $\begin{array}{l}.30 \\
(.15)\end{array}$ \\
\hline Job satisfaction & .10 & $\begin{array}{l}.27 \ddagger \\
(.27)\end{array}$ & $\begin{array}{l}-.20 \\
(-.16)\end{array}$ & $\begin{array}{c}.03 \\
(.03)\end{array}$ & $\begin{array}{c}-.04 \\
(-.04)\end{array}$ & $\begin{array}{c}-.03 \\
(-.01)\end{array}$ \\
\hline Tactical responses & $.28 \|$ & $\begin{array}{l}.10 \\
(.12)\end{array}$ & $\begin{array}{l}-.09 \\
(-.08)\end{array}$ & $\begin{array}{l}.15 \\
(.13)\end{array}$ & $\begin{array}{l}.278 \\
(.30)\end{array}$ & $\begin{array}{c}1.08 \| \\
(.45)\end{array}$ \\
\hline Defensive orientation & .331 & $\begin{array}{c}-.12 \\
(-.13)\end{array}$ & $\begin{array}{c}.56 \| \\
(.45)\end{array}$ & $\begin{array}{c}-.16 \\
(.14)\end{array}$ & $\begin{array}{l}.27 \ddagger \\
(.27)\end{array}$ & $\begin{array}{c}-.09 \\
(-.04)\end{array}$ \\
\hline
\end{tabular}

* Sample Beta's and partial correlations.

$\dagger$ Numbers in parentheses are the partial correlations of the independent variables with the dependent variable controlling for the other independent variables.

$\neq p<.05$.

$\S p<.01$.

\|l $p<.005$. 
TABLE 6. Regressions of the measures of supervisors' uses of control systems on measures of subordinate responses-high participation, low job difficulty ${ }^{\dagger}$

\begin{tabular}{lcccccc}
\hline $\begin{array}{c}\text { Subordinate } \\
\text { responses }\end{array}$ & $r^{2}$ & $\begin{array}{c}\text { Use for } \\
\text { problem solving* }\end{array}$ & $\begin{array}{c}\text { Use for } \\
\text { goal setting* }\end{array}$ & $\begin{array}{c}\text { Use for } \\
\text { evaluation* }\end{array}$ & $\begin{array}{c}\text { Use for } \\
\text { contingent } \\
\text { reward } \\
\text { allocation* }\end{array}$ & $\begin{array}{c}\text { Managerial } \\
\text { level* }\end{array}$ \\
\hline Effort & $.22 \|$ & $.17 \neq$ & $.25 \neq$ & $.23 \S$ & -.08 & .23 \\
Job satisfaction & .06 & $(.19)$ & $(.23)$ & $(.25)$ & $(-.08)$ & $(.18)$ \\
Tactical responses & $.16 \|$ & .07 & .02 & .09 & $-.17 \neq$ & -.11 \\
Defensive orientation & $.20 \|$ & $(.08)$ & $(.02)$ & $(.09)$ & $(-.19)$ & $(-.08)$ \\
& & $(-.03)$ & $.30 \ddagger$ & .12 & -.05 & $.40 \S$ \\
& $(-.22 \ddagger$ & $.11)$ & $(.10)$ & $(-.14)$ & $.34)$ & .408 \\
\end{tabular}

* Sample Beta's and partial correlations.

$\dagger$ Numbers in parentheses are the partial correlations of the independent variables with the dependent variable controlling for the other independent variables.

$\ddagger p<.05$.

$\S p<.01$.

$\| p<.005$.

TABLE 7. Regression of measures of supervisors' uses of control systems on measures of subordinate responses-high participation, high job difficulty $\dagger^{\dagger}$

\begin{tabular}{lcccccc}
\hline $\begin{array}{c}\text { Subordinate } \\
\text { responses }\end{array}$ & $r^{2}$ & $\begin{array}{c}\text { Use for } \\
\text { problem solving* }\end{array}$ & $\begin{array}{c}\text { Use for } \\
\text { goal setting* }\end{array}$ & $\begin{array}{c}\text { Use for } \\
\text { evaluation* }\end{array}$ & $\begin{array}{c}\text { Use for } \\
\text { contingent } \\
\text { reward } \\
\text { allocation* }\end{array}$ & $\begin{array}{c}\text { Managerial } \\
\text { level* }\end{array}$ \\
\hline Effort & .168 & .10 & .14 & .13 & .02 & .07 \\
Job satisfaction & .188 & $(.15)$ & $(.14)$ & $(.19)$ & $(.04)$ & $(.10)$ \\
Tactical responses & $.28 \|$ & $(.06)$ & .388 & -.15 & .09 & -.24 \\
& & .24 & -.03 & $(-.14)$ & $. .11)$ & $(-.22)$ \\
Defensive orientation & $.26 \|$ & $(.20)$ & $(-.02)$ & $(.16)$ & $.39 \|$ & $.36 \neq$ \\
& & $(-.19)$ & $.40 \neq$ & -.18 & $.38)$ & $(.27)$ \\
& & & $(.24)$ & $(-.15)$ & $(.34)$ & $.28 \neq$ \\
\hline
\end{tabular}

* Sample Beta's and partial correlations.

$\dagger$ Numbers in parentheses are the partial correlations of the independent variables with the dependent variable controlling for the other independent variables.

$\neq p<.05$.

$\S p<.01$.

$\| p<.005$.

variables had significant weights. Further analyses indicated that the measures of use for problem solving, goal setting, and evaluation all related significantly to effort $(r=.34, .22, .29$, respectively), but that they suffered from problems of multicollinearity $(r=-.04, .44$, $.42)$. This indicates that these three variables together do relate to effort, but that they are not sufficiently independent to have significant independent contributions. 
TABLE 8. Regression analysis relating perceptions of control system uses with subordinate responses, using derived use for development measure

\begin{tabular}{|c|c|c|c|c|c|c|}
\hline $\begin{array}{l}\text { Contextual } \\
\text { condition }\end{array}$ & $\begin{array}{l}\text { Subordinate } \\
\text { response }\end{array}$ & $r^{2 *}$ & $\begin{array}{l}\text { Use for } \\
\text { goal setting } \dagger\end{array}$ & $\begin{array}{l}\text { Use for } \\
\text { contingent } \\
\text { reward } \\
\text { allocation }\end{array}$ & $\begin{array}{l}\text { Use for } \\
\text { development } \dagger\end{array}$ & $\begin{array}{l}\text { Managerial } \\
\text { level } f\end{array}$ \\
\hline $\begin{array}{l}\text { Low participation, } \\
\text { Low job difficulty }\end{array}$ & $\begin{array}{l}\text { Effort } \\
\text { Job satisfaction } \\
\text { Tactical responses } \\
\text { Defensive orientation }\end{array}$ & $\begin{array}{l}.15 \| \\
.06 \\
.15 \\
.17 \|\end{array}$ & $\begin{array}{r}-.10 \\
-.05 \\
.13 \\
.12\end{array}$ & $\begin{array}{c}-.14 \\
-.20 \\
.18 \\
.34 \|\end{array}$ & $\begin{array}{l}.34 \| \\
.14 \\
.01 \\
-.29 \S\end{array}$ & $\begin{array}{l}-.18 \\
-.17 \\
.328 \\
.21 \neq\end{array}$ \\
\hline $\begin{array}{l}\text { Low participation, } \\
\text { High job difficulty }\end{array}$ & $\begin{array}{l}\text { Effort } \\
\text { Job satisfaction } \\
\text { Tactical responses } \\
\text { Defensive orientation }\end{array}$ & $\begin{array}{l}.10 \\
.08 \\
.288 \\
.32 \| \\
\end{array}$ & $\begin{array}{l}-.12 \\
-.15 \\
-.09 \\
.45\end{array}$ & $\begin{array}{c}.27 \ddagger \\
-.14 \\
.35 \| \\
.298\end{array}$ & $\begin{array}{c}.10 \\
.25 \ddagger \\
.14 \\
-.16 \\
\end{array}$ & $\begin{array}{c}.15 \\
.00 \\
.45 \| \\
-.04 \\
\end{array}$ \\
\hline $\begin{array}{l}\text { High participation, } \\
\text { High job difficulty }\end{array}$ & $\begin{array}{l}\text { Effort } \\
\text { Job satisfaction } \\
\text { Tactical responses } \\
\text { Defensive orientation }\end{array}$ & $\begin{array}{l}.23 \| \\
.08 \\
.15 \ddagger \\
.18 \|\end{array}$ & $\begin{array}{l}.23 \neq \\
.02 \\
.21 \neq \\
.07\end{array}$ & $\begin{array}{l}-.08 \\
-.22 \ddagger \\
-.01 \\
.37 \|\end{array}$ & $\begin{array}{l}.3111 \\
.14 \\
.08 \\
-.19 \\
\end{array}$ & $\begin{array}{l}.19 \\
.08 \\
.3211 \\
.258 \\
\end{array}$ \\
\hline $\begin{array}{l}\text { High participation } \\
\text { High job difficulty }\end{array}$ & $\begin{array}{l}\text { Effort } \\
\text { Job satisfaction } \\
\text { Tactical responses } \\
\text { Defensive orientation }\end{array}$ & $\begin{array}{l}.168 \\
.16 \neq \\
.29 \| \\
.25 \|\end{array}$ & $\begin{array}{l}.15 \\
.29 \S \\
-.02 \\
.22 \ddagger\end{array}$ & $\begin{array}{l}.06 \\
.06 \\
.40 \| \\
.37 \|\end{array}$ & $\begin{array}{l}.21 \ddagger \\
-.08 \\
.24 \ddagger \\
-.18\end{array}$ & $\begin{array}{l}.10 \\
.20 \\
.28 \S \\
.21\end{array}$ \\
\hline
\end{tabular}

* Significance of $r^{2}$ is a test of the significance of the contribution of the uses of the control systems excluding managerial level.

$\dagger$ Partial correlations of the independent variable with the dependent variable controlling for the other independent variables.

$\neq$ Beta significant $p<.05$.

$\S$ Beta significant $p<.01$.

$\|$ Beta significant $p<.005$.

\section{Discussion}

The data presented here reveal a number of interesting patterns. First, the measures of the use for problem solving and evaluation generally related to functional responses while being either unrelated or negatively related to dysfunctional ones. These results indicate that it was generally functional for managers to use the control systems for helping their subordinates identify and solve work-related problems, and for holding them accountable for their performance. Further, the general similarity of the relationship between these measures and the measures of subordinate responses suggests that, in spite of their relative independence $(r=-.14)$, they represent two different dimensions of a single pattern of using control systems. Holding subordinates accountable for their performance and helping them solve problems which arise could both be aspects of a developmental, collaborative use of control systems. By holding the subordinates responsible for their results, the superiors indicate that performance is important, and that the subordinates need to increase their competence as managers. By using the control system information to help the subordinates solve work-related problems the superiors facilitate performance improvements and the subordinates provide concrete examples of ways to manage more effectively.

In order to test the possibility that these two different uses of control system information were actually two aspects of a single pattern of use, a new measure - use for development - was created by multiplying the measure of use for evaluation with the measure of the use for problem solving. The regressions presented in Tables 4-7 were then recalculated using this measure of the interaction of the uses for evaluation and problem solving in place of these two measures. The results are shown in Table 8. None of the new regressions explained a significantly different amount of variance in the 
dependent variables. In seven of the regressions, less variance in the dependent variables was explained; in five there was no difference, and in four of them, more variance was explained. These results support the hypothesis that the use of the control system for evaluation and problem solving are two different aspects of a single developmental use pattern.

In addition, the results shown in Table 8 also indicate that the developmental use of control systems was more strongly related to functional subordinate response patterns under conditions of low perceived job difficulty and high perceived participation in decision making. This pattern provides additional support for the interpretation that this is a developmental use of the control system since low stress and high commitment are conditions which are traditionally associated with success in learning complex tasks.

The results describing the subordinates' responses to their perceptions that control system information was used as a basis for contingent reward allocation showed a very different pattern. When the subordinates felt that their superiors used the control system information as a basis for allocating organizational rewards, their responses were dysfunctional under all conditions, and they only responded with the functional response of effort under conditions of low participation and high job difficulty. This pattern of results indicate that using control systems for contingent reward allocation did have the effect of motivating the subordinates to keep their performance measures high, but they usually tried to achieve this through dysfunctional responses. They only tried to keep their measures high by working harder when their superiors were able to monitor their behavior closely enough to insure that effort was being expended (e.g. when participation was low) and when they had to work hard in order to perform well (e.g. job difficulty was high).

The results also indicated that subordinate participation in decision making was a critical factor moderating subordinate responses to the use for goal setting. When participation was low, the subordinates' perceptions of the use for goal setting did not relate to functional responses, and related strongly to having a defensive orientation if they felt their jobs were difficult. On the other hand, when participation was high, this perception related to functional responses, although it also related slightly to having a defensive orientation when the subordinates felt they had difficult jobs.
Together, these results imply that using the control systems for structuring subordinate goals was generally functional when subordinates participated in decision making, and generally dysfunctional when they did not.

One puzzling aspect of the results was the small number of significant relationships between the measures of control system use and job satisfaction. Only two of these relationships were significant. The use for problem solving was positively related to job satisfaction under conditions of low job difficulty and low participation, and the use for goal setting was positively related to satisfaction under conditions of high subordinate participation and high job difficulty. None of the other relationships were significant, either positive or negative. While there are probably a number of explanations for the general lack of relationship between control system use and subordinate satisfaction, the most parsimonious appears to be that most uses of control systems are inherently neither satisfying nor dissatisfying. The critical factor is probably the subordinates' job performance. When their job performance is high, most of the uses are likely to produce satisfaction; when performance is low, dissatisfaction. This would explain the lack of relationships observed in this study.

\section{THEORETICAL IMPLICATIONS}

The results of this study have a number of implications for theories concerning the behavioral impact of control systems in organizations. At a general level they demonstrate clearly the responses to different uses of control systems will vary as a function of the contexts in which they are used. Theory and research in this area needs to examine more closely the ways in which specific patterns of use stimulate different patterns of responses. These relationships are not uniform, and as a result, uses which are effective in one context are likely to be ineffective, or dysfunctional, in another.

More specifically, the results of this study seem to imply that there are at least three quite different patterns of using control systems which can prove effective for influencing subordinate behavior in hierarchical organizations. Each of these appears to have different effects on subordinates, and each appears to be effective in different situations. 
The first pattern involves using the control system information to hold subordinates accountable for their results, and to help them identify and solve performance problems without primitively evaluating them for poor results. This pattern of using control system information for developmental evaluation appears to produce generally functional subordinate responses, but seems to be most useful when subordinates feel that their jobs are relatively easy and their participation in decision making relatively high.

These results appear to be basically consistent with predictions which have been made by theorists such as McGregor (1960) and Argyris (1964). They have advocated a developmental approach to performance evaluation in which control system information forms one input to a critical review of past subordinate action. The central elements of this review process are a collaborative exploration of the subordinates' strengths and weaknesses, and the development of concrete plans for improving future performance. Argyris and McGregor have predicted that subordinates will experience this type of evaluation as helpful, although possibly painful, and that they will respond by accepting personal responsibility for their past performance, and by working hard to improve their performance in the future.

Overall, the conclusions from this study appear to be quite congruent with these predictions. This implies that control systems can be useful tools for motivating subordinates to develop their skills and improve their performance, as long as the control system information is used as a basis for developmental problem solving, and that this use will be most effective when the subordinates have relatively easy job goals and participate in decision making. 4

The second pattern involves using control system measures for clarifying performance expectations through goal setting. The results of this study imply that this use of control systems will produce functional subordinate responses when the subordinates participate in decision making, and dysfunctional ones when they do not. Theoretically, this pattern of results suggests that the use for goal setting is valuable for motivating subordinates to perform well when the goals serve to clarify agreements which are developed through a process of mutual influence, but that it will simply motivate resistance if the goals are used to impose difficult performance standards.

These conclusions are consistent with previous research indicating that control system goals which are developed participatively will have a positive motivating effect on subordinates (Hofstede, 1967; Searfoss \& Monczka, 1973). They also provide considerable support for Tosi's contention that the amount of subordinate participation in decision making is the critical factor in determining subordinate responses to the use for goal setting, not the amount of participation in the goal setting itself. From this perspective Hopwood's (1973) finding that subordinates use participation in goal setting to increase the effectiveness of defensive responses in the context of generally non-participative superior-subordinate relationships appears quite reasonable.

The final pattern of use involves making organizational rewards and penalties directly contingent on control system results. The results of the study lead to the conclusion that this use of control system information will always result in dysfunctional responses as subordinates try to insure that their measured results are high. However, it can also produce the functional result of effort when subordinates have difficult jobs and don't participate in decision making. This suggests that contingent reward allocation can be a useful strategy for motivating subordinates in the context of non-participative superior-subordinate relationships. The problem, of course, is that it is only useful if the subordinates have difficult jobs. One solution to this problem would be for superiors in this situation to use the control system to impose difficuit performance goals, thus insuring the subordinates have difficult jobs, and then to make organizational rewards contingent on achieving the goals. This autocratic strategy has been suggested by contingency theorists (Lawler, 1971, 1976), and should result in both defensive response and high levels of effort. As long as the superiors have adequate controls for reducing the effectiveness of the defensive responses, this usage pattern might prove organizationally functional.

\footnotetext{
4Te fact that the developmental use of control systems is most functional under conditions of low job difficulty and high participation are also consistent with Argyris' and McGregor's predictions, since they both argue that learning is most likely to occur when the risks associated with failure are not too high, and when the subordinates feel personally responsible for the results they achieve.
} 


\section{CONCLUSION}

The purpose of this study was to explore the possibility that the effects of the use of control systems were moderated by the situational characteristics of subordinate participation in decision making and experienced job difficulty. Although the methodology used was correlational, and the measures were based on subordinate perceptions, the results seemed to demonstrate fairly clearly that the situational moderators did make a difference.

Further, the relationships between the measures of control system use and subordinate responses observed in the organization studied here suggest a number of propositions about effective control system use. It appears that the use of control systems for developmental evaluation will produce generally functional subordinate responses, but that this use will be most functional when subordinates have relatively easy jobs and when they participate in decision making. Using control systems to clarify performance expectation through goal setting appears to produce the best organizational results when subordinate participation is high. Finally, the use of control systems to autocratically motivate subordinates to perform well through contingent reward allocation appears to produce the best results in the context of nonparticipative superior-subordinate relationships when the superiors can impose difficult performance standards on the subordinates.

Further research needs to test the validity of these propositions and the impact of other contextual conditions which may moderate the effects of control system use. For example, it seems likely that the patterns of interdependencies among organizational members, the degree of uncertainty in the task environment, and the nature of the organizations material and information handling technologies will all moderate the effects of control system uses. A great deal more research is necessary before we will know which uses of control systems produce functional results in the wide variety of situations where they are used. In addition, longitudinal and experimental studies are necessary to examine the causal directions of the relationships which are dis. covered. While it seems reasonable to assume that supervisory uses of control systems will stimulate subordinate responses, this assumption needs to be empirically justified.

\section{BIBLIOGRAPHY}

Argyris, C., The Impact of Budgets on People (Ithaca, New York: Cornell University, School of Business and Public Administration, 1952).

Argyris, C., Interpersonal Competence and Organizational Effectiveness (Homewood, Ill.: Irwin Dorsey, 1962).

Argyris, C., Integrating the Individual and the Organization (New York: J. Wiley, 1964).

Blau, P. M., Bureaucracy in Modern Society (New York: Random House, 1956).

Coch, L. \& French, J. R. P., Overcoming resistance to change, Human Relations (1948), pp. 512-532.

Deutsch, M. \& Krauss, R., Studies of interpersonal bargaining, Conflict Resolution (1962), pp. 52-76.

French, J. R. P., Kay, E. \& Meyer, H., Participation and the appraisal system, Human Relations (1966), pp. 3-19.

Hofstede, G. H., The Game of Budget Control (Assen, Netherlands: Van Gorcum, 1967).

Hopwood, A.G., An Accounting System and Managerial Behavior (Lexington, Mass.: Lexington Books, 1973).

Hopwood, A. G., Accounting and Human Behavior (London: Haymarket Publ., 1974).

Jasinsky, F. J., Use and misuse of efficiency controls, Harvard Business Review (1956), pp. 105-112.

Kerlinger, F. N. \& Pedhauzur, E. J., Multiple Regression in Behavioral Research (New York: Holt, Rinehart \& Winston, 1973).

Lawler, E. E., Pay and Organizational Effectiveness: A Psychological View (New York: McGraw-Hill, 1971).

Lawler, E. E., Control systems in organizations. In M. Dunnette, ed., Handbook of Industrial and Organizational Psychology (Chicago: Rand McNally, 1976).

McGregor, D., The Human Side of Enterprise (New York: McGraw-Hill. 1960).

Onsi, M., Factor analysis of behavioral variables affecting budgetary slack, The Accounting Review (1973), pp. 535-548.

Searfoss, D. \& Monczka, R., Perceived participation in the budget process and motivation to achieve the budget, Academy of Management Journal (1973), pp. 541-554. 
Stedry, A. C., Budget Control and Cost Behavior (Englewood Cliffs, N.J.: Prentice-Hall, 1960).

Stedry, A. C. \& Kay, E., The Effects of Goal Difficulty on Performance (Publication BRS-19; New York: Behavioral Research Service, G. E. Crontonville, 1964).

Tannenbaum, A. S., Control in organizations: Individual adjustment and organizational performance, Administrative Science Quarterly (1962), pp. 236-257.

Tosi, H., The human effects of managerial budgeting systems. Paper presented at the Workshop in Behavioral Accounting, Annual Meeting of the American Institute for Decision Sciences, Atlanta, Georgia (October, 1974).

Vroom, V. H., Work and Motivation (New York: J. Wiley, 1964).

Whyte, W. F., ed., Money and Motivation: An A nalysis of Incentives in Industry (New York: Harper \& Row, 1955). 